\title{
1 The Reception of Magentenos' Work and Modern Scholarship on him: an Overview
}

\subsection{Reception}

The locus communis of scholarship concerning Leon Magentenos is the uncertainty that surrounds both his identity and the exact date of his work. ${ }^{1}$ However, the dissemination of codices that contain the works of this Byzantine scholar highlights his influence. Magentenos wrote commentaries on Porphyrios' Isagoge and seemingly on all of Aristotle's logical works, that is, the Organon. ${ }^{2}$

Of particular interest is the manuscript tradition of Magentenos' work on Int., Anal. Pr. and the Anal. Post. Regarding the first treatise, there are three commentaries ascribed to the Byzantine philosopher. Besides the textus receptus, ${ }^{3}$ there also exists a commentary on Int. printed by Aldus Manutius in Venice (1503). ${ }^{4}$ Adolf Busse disputed the authenticity of the latter text, ${ }^{5}$ but Börje Bydén has recently explained his reasons for thinking that this work might indeed have been authored by Magentenos. ${ }^{6}$ Moreover, there is a third commentary transmitted in Vat. gr. 2173 (15th c.) that bears no resemblance to the other two mentioned. ${ }^{7}$ As for dubia, we may point to two later codices which transmit individual scholia on the Anal. Pr. attributed to Magentenos. These differ from one another, as well as from the the rest of the textual witnesses. ${ }^{8}$

1 On Leon Magentenos see Ebbesen 1981b, I, 302-303; Kaldellis - Efthymiadis 2010, n. 233; Bydén 2011, 684-685; CAGB Database (link to the lemma on p. XXIII).

2 An elementary search in the Pinakes database reveals thirty-one manuscripts attributed to Magentenos (see link on p. XXIII; the reference to Par. gr. 2061 is an error, since this codex does not transmit any work of Magentenos); on this codex see p. XLIII. For the manuscript tradition of the commentary on the Anal. Pr., see below p. XLVII.

3 See Vat. gr. 244, ff. 91r-132v. The codex Par. gr. 1917 (13th c.) transmits the text with a different beginning (ff. 17r-24v, 1. 24), which, according to Busse, is due to a later scholar replacing the missing part by compiling material from other commentators (Busse 1897, xxxix-xli).

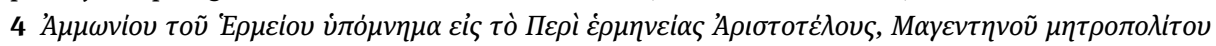

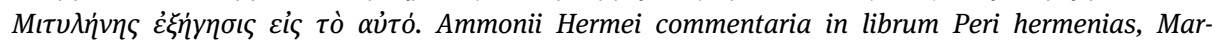
gentini archiepiscopi Mitylenensis in eundem enarratio, Venedig 1503, ff. I 1r-L 3v; from now on Ps.-Magentenos (?). This commentary was republished in Venice (1520), and then translated into Latin several times: Venice 1539, Paris 1544, Venice 1545, Lyon 1547 (with the last translation of the commentary on the Anal. Pr.); cf. Benakis 1987, 358. Ps.-Magentenos (?) is transmitted in the following manuscripts: Ambr. D 54 sup. (1272; ff. 114r-129r, ascribed to Ioannes Philoponos: ả

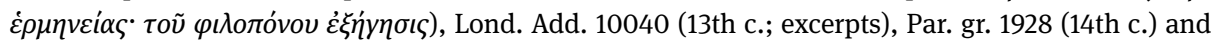
Vind. Phil. gr. 10 (14th/15th c.).

5 Busse 1897, xli-xlii.

6 Bydén 2011, 684-685.

7 Lilla 1985, 40-41. We are currently preparing a digital critical edition of this text.

8 See below p. XLVII. 
A short text on the number of the so-called 'predicables' is transmitted anonymously in Vat. gr. 244, f. 32r and Par. Coisl. 170, ff. 173v-174v, whereas it was registered as

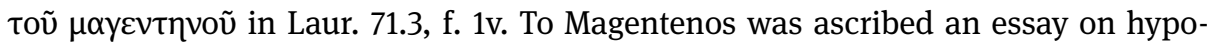
thetical syllogisms in Laur. 71.33, ff. 145v-146v. ${ }^{9}$ Moreover, when Max Wallies edited a commentary on Anal. Post. II under the name of Ioannes Philoponos, ${ }^{10}$ he actually argued in the preface to his edition that the work should not be attributed to Philoponos. ${ }^{11}$ Owen Goldin is also doubtful of Philoponos' authorship, and suggests that this work might be a condensed paraphrasis of a now lost commentary of Philoponos on Anal. Post. II, or of comments deriving from Ammonios' lectures. ${ }^{12}$ In a recent article, however, Sten Ebbesen is probably right in attributing this text to Magentenos on palaeographic and stylistic grounds. ${ }^{13}$

With regard to Byzantine scholars who must have used or at least known Magentenos' work, we should first mention the commentary on the Anal. Pr. in Vat. Urb. gr. 35 (see p. LXXIII), as well as the copyist (that is, the interpolator) of his texts in Vat. gr. 244 (see pp. LXIII and LXXVI). Three lists deriving from the late Byzantine period record some of Magentenos' works. ${ }^{14}$ Firstly, the inventory in Marc. gr. 203 (13th/14th c.) includes allusions to commentaries on Porphyrios' Isagoge, Cat., and Int. ${ }^{15}$ Secondly, the register in Vat. gr. 241 (14th c.) transmits a reference to a commentary on the Anal. Pr. $^{16}$ Finally, the list in Rom. Ang. 42 (14th c.) mentions all four works. ${ }^{17}$ There is also a fourth, older, list which is preserved in the codex Hieros. Patr. 106 (13th c.). It contains, however, no information on Magentenos. ${ }^{18}$ Ioannes Pediassimos (ca. 1274/ 1310-1314) had, perhaps, some knowledge of Magentenos' commentary on Anal. Pr. or employed the same source as Magentenos did. ${ }^{19}$ The monk Sophonias (13th/14th c.) must, in all probability, be the anonymous author who employed Magentenos' commentary on the Soph. El. in his paraphrase of the corresponding Aristotelian treatise. ${ }^{20}$ The scholar Isaac Argyros (ca 1300/1310-1375) used Magentenos' commentaries on the Top. and the Soph. El. for his interpolated versions of Alexander's commentaries, which are both transmitted in Neap. BN gr. III D 37 (321). ${ }^{21}$ Scholia of Magentenos on

9 See below p. LX.

10 Wallies 1909, 334-440.

11 Wallies 1909, v-vi. See also Cacouros 1996, 92-93.

12 Goldin 2009, 3-4.

13 Ebbesen 2015, 13.

14 See also Harlfinger 1971, 99.

15 Usener 1865, 135-136.

16 Hayduck 1885, v.

17 See the detailed description by D. Reinsch (June 1967) on the website of the CAGB Database.

18 Wendland 1901, xvii-xix.

19 See the Index locorum of the present edition. On the edition of the scholia of Pediassimos see De Falco 1926 and 1928.

20 Ebbesen 1981b, I, 333-336.

21 Ebbesen 1981b, I, 321-322; González Calderón 2014, 295, 309-317. 
the Top. where also put to use by Ioannes Chortasmenos (ca. 1370 - ca. 1436/37) in

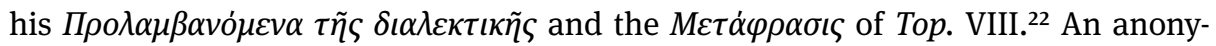
mous scholiast of the late 14 th or early 15th c. wrote comments on the Soph. El. using the respective treatise written by Magentenos as his source. ${ }^{23}$ Vind. Phil. gr. 65 (15th

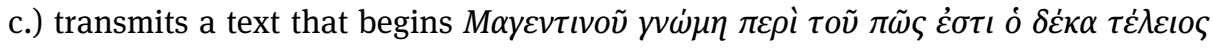
$\dot{\alpha} \rho \imath \mu o_{\varsigma}$ (ff. $4 \mathrm{r}-9 \mathrm{v}$ ). This is not actually a mathematical treatise written by Magentenos, as has been suggested by Johan Ludvig Heiberg and other scholars, but is in fact an anonymous text that integrates an excerpt from Magentenos' commentary on the Cat. ${ }^{24}$ Towards the end of the Byzantine period, the Patriarch Gennadios Scholarios (ca. 1400 - after 1472) asserts - in spite of his criticism of Magentenos' scholia on Int. ${ }^{25}$ - that Magentenos was at the time actually rather in favour as a commentator. ${ }^{26}$ Gennadios, Bessarion (1399/1400-1472) and their teacher, Chortasmenos, were actually involved in producing an interpolated version of Theodoros Prodromos' commentary on Anal. Post. II. Chortasmenos' interpolations include extracts from Ps.-Philoponos' commentary on Anal. Post. II, which are attributed to Magentenos. ${ }^{27}$ Both Gennadios and Bessarion had in their possession copies of the latter work, ${ }^{28}$ mostly likely based on their tutor's manuscript. ${ }^{29}$

Two commentaries were printed under the name of Magentenos and then frequently translated into Latin during the sixteenth century. Ph. Labbé (1607-1667) is, to our knowledge, the first to provide information on these editions; he mentions the

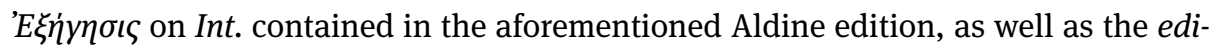
tio princeps of the commentary on the Anal. Pr. by V. Trincavelli (Venice 1536). ${ }^{30}$ of particular interest is the copy of the Basel edition of the complete works of Aristotle which is currently exhibited in the Iviron Monastery museum on Mount Athos. Theophanes Eleavourkos (ca. 1500 - before July 1556), was once the owner of this volume

22 Kotzabassi 1999, 14-15.

23 Ebbesen 1981b, I, 317-320.

24 Vind. phil. gr. 65, f. 4r, vv. 3-10. The author himself introduces the excerpt after informing the

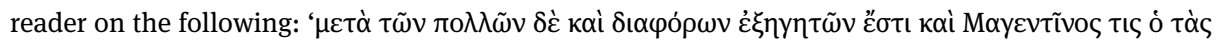

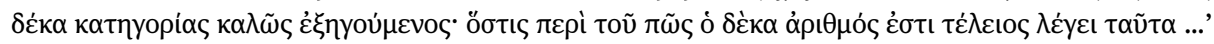
(f. 4r, vv. 2-3); cf. Heiberg 1899, 164; Hunger 1961, 182.

25 Cacouros 2015, 43.

26 Jugie 1936, VII, 3.79; Ebbesen 1981b, I, 303.

27 Cacouros 1994-95, 339-348; Cacouros 1996, 92-96; Ebbesen 2015, 13; Agiotis 2016; Valente 2021 b.

28 Par. gr. 1932 and Marc. gr. 202 respectively

29 Leuven MS. FDWM 1.

30 Labbé 1657, 9-10. For the edition and the translations of this work in Latin, see pp. LX sqq. Almost two decades later, G. M. König (1616-1699) reproduces this information, but with a slightly different

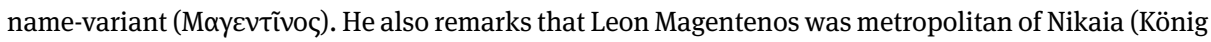
1678, 493). This could indicate that König has confused Leon Magentenos and Ignatios Magentinos (on Ignatios Magentinos see p. XXXVII). 
and added scholia deriving from various sources in the margins. ${ }^{31}$ Some of these scholia transmit Magentenos' commentary on the Anal. Pr. Unfortunately, the excerpts from Magentenos' work came to our notice too late to take them into consideration here, but an initial inquiry suggests that they depend on the editio princeps.

Almost a century later, Nikolaos Komnenos-Papadopoulos (1651-1740) mentions in his Praenotiones mystagogicae (Padua 1697) that Magentenos flourished around the year 1300 and was teacher of Konstantinos Armenopoulos (1320 - ca. 1385). ${ }^{32}$ According to Komnenos-Papadopoulos, Magentenos wrote not only commentaries on the Aristotelian logic, ${ }^{33}$ but also texts on numerous subjects. ${ }^{34}$ However, Komnenos-Papadopoulos' treatise is well-known for its inaccuracies. Consequently, any effort to identify the 'sources' of his work would most likely be misdirected. ${ }^{35}$ The negative reception of the Praenotiones by the Greek Orthodox Church, however, resulted in its partial translation (or, more accurately, its paraphrase) into Greek probably not long after its publication. ${ }^{36}$ The translators' purpose was to provide means for the Patriarch of Jerusalem Dositheos II (1641-1707) to understand the original Latin text so that he might then adapt the translated passages for his History of the Patriarchs of Jerusalem, a text which would be known later as the 'Dodekabiblos'. ${ }^{37}$ Neither Dositheos nor his collaborators seem to have been aware of the extent and number of Komnenos-Papadopoulos' factual errors. That said, they may well have suspected a fictitious reference to Magentenos in one instance; both Greek texts - Chrysanthos' translation and the 'Dodekabiblos' - include citations (book and chapter numbers) of an alledged treatise by Magentenos, but there is no mention of its title, as occurs in

31 Agiotis 2021a.

32 Papadopoulos 1697, 8b, 143b; see also Ebbesen 1981b, I, 303.

33 Papadopoulos 1697, 8a-b deems, apparently, that V. Trincavelli edited only the comments of Leon on Int.: 'Leo Magentinus Metropolites Mitylenaeus elegantissimae vir Sapientiae, cujus Commentarios

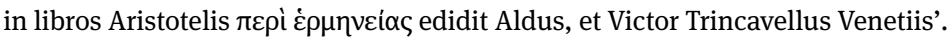

34 Papadopoulos 1697, 8b (De neglectis canonum praeceptis), 116b (In expositione Regulam Nicephori Patriarche, in medio), 213b (De veteris philosophis), 214 (De moribus Asiaticis), 220a (Explicatio canonum poenitentialium Petri Alexandrini), 226a (De arcana philosophia), 233a (Explicatio canonum poenitentialium Gregorii Thaumaturgi), 235b (scholia on Pol.), 253b (scholia on An.), 281a (scholia on $E N), 287 b$ (De moribus gentium), 387a (scholia on Gener. Corr.).

35 Podskalsky 1988, 302: 'Dieses Buch enthält neben einer beeindruckenden Materialfulle so viele sachliche Fehler, dass man daran zweifeln kann, ob diese der Flüchtigkeit oder der bewußten Täuschung zuzuschreiben sind'.

36 Critical edition Garitsis 2012; see especially pages $\xi \beta^{\prime}-o \beta^{\prime}, o \zeta^{\prime}-\pi^{\prime}$.

37 Dositheos 1715; for the relationship between 'Dodekabiblos' and the translated Praenotiones, see Garitsis 2012, $\lambda \alpha^{\prime}-\mu \zeta$. The former work was edited and then published posthumously by Chrysanthos Notaras (1655/1660-1731). Chrysanthos was Dositheos' nephew and successor to the patriarchal throne of Jerusalem, as well as one of the two translators of the Praenotiones. 'Dodekabiblos' was published later than is suggested by its frontpage (1715) - possibly in 1722; see Sarris 2005, 32-41. 
the Latin text. Apparently, this was not the applied method for titles of other works in the same passage. ${ }^{38}$

Magentenos continued to be read by Greeks even as late as the eighteenth century. His influence is attested, for instance, by a diagram in the codex Lond. Add. 7143 (f. $369 r)^{39}$ that classifies the scholar among those scholiasts who wrote commentaries on Cat. and Int. This manuscript was copied and used in a Greek school of Constantinople not long prior to 1712. Another example derives from the controversy between the ardent Neo-Aristotelian Dorotheos Lesbios ( +1770$)$ and his opponent Nikolaos Zerzoules (ca. 1709-1772/73); Zerzoules invokes Magentenos - much like Gennadios did - as a favoured Aristotelian author in an attempt to defend his expertise on Aristotle against Lesbios in $1759 .{ }^{40}$ Furthermore, Eugenios Voulgaris (1716-1806) mentions in the footnotes to his Logic (Leipzig 1766) comments of Magentenos on the Anal. Pr. ${ }^{41}$

38 Magentenos' fictional work in the Praenotiones is the De veteris philosophis. In both Greek texts the respective citation has been adapted without mentioning the title in the latin text. (In textu numbers of the Praenotiones below correspond to marginal notes of this edition. We print in bold the references to the De veteris philosophis.)

I. Papadopoulos 1697, 213b: 'Quod de Barba diximus, idipsum habe de coma: nam et Romani prisei illi capillos aluere, et posteri Priscorum tondebantur, ut eruditis translatiuum est, et Numi testantur. At Graeci omni aevo, donec in Latinorum mores cessere, prolixa celarie gaudebunt; unde perpetuum

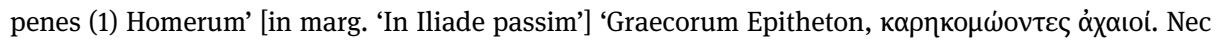
Graecis modo, sed Orientalibus populis passim usus Barbae, capillique, ut constat ex iis, quae narrat (2) Ctesias' [in marg. 'In fagmen. frag. 3'] '(3) Herodotus' [in marg. 'In Urania'] '(4) Jambilicus' [in marg. 'In Vita Solonis'] '(5) Heraclides' [in marg. 'In Vita Pittaci'] 'aliique videndi penes (6) Magentinum' [in marg. 'De Vet. Philosoph. li. 2.c.11'] 'qui ex Poetis idem deducit, praesertimque ex (7) Oppiano' [in marg. 'Halieut. li. 2'] 'et (8) Nonno' [in marg. 'Dionysiac. lib. 9'].

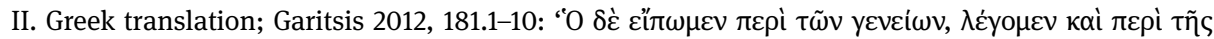

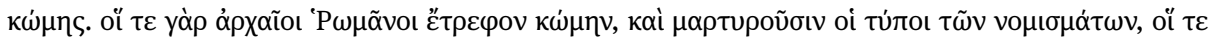

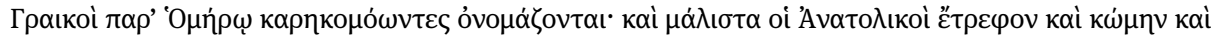

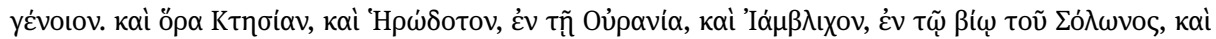

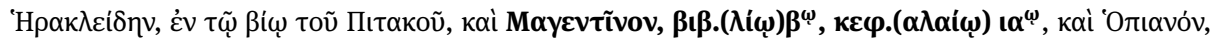

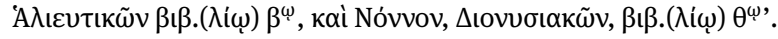

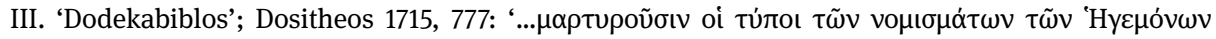

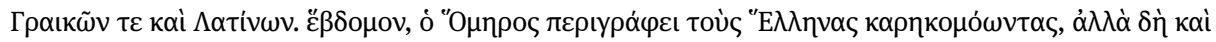

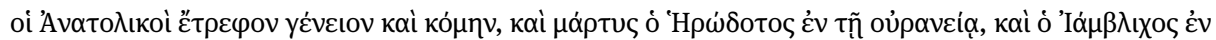

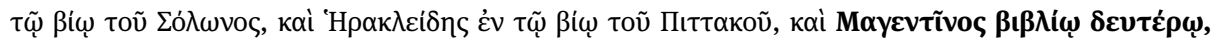

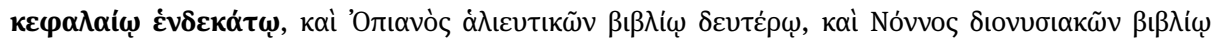
¿́vó̀ $\omega^{\prime}$.

39 Link to the digitised copy on $\mathrm{p}$. XXII.

40 Benakis 1977, 435-436.

41 Voulgaris 1766, 382 (2), 466 (1); cf. Anal. Pr. I 3, 25 b19 sqq. and 1, 24 b16 sqq. respectively. 


\subsection{Modern Scholarship}

In more recent times, it was decided that Magentenos' works should constitute part of the Royal Prussian Academy of Sciences's Commentaria in Aristotelem Graeca series (CAG 1891-1909). On 9th May 1878, during a meeting of the Academy, Eduard Zeller (1814-1908) presented, on behalf of the CAG editorial board, a draft list of the Aristotelian commentaries to be published in the new series; the twenty-fourth volume was to include Magentenos' treatises. ${ }^{42}$ The appropriate preparatory work on Magentenos was conducted by Adolf Torstrik ${ }^{43}$ (1821-1877), the first editor of the CAG, during two trips to consult libraries in Italy (1876), ${ }^{44}$ Paris, Oxford and Madrid (1877). ${ }^{45} \mathrm{It}$ seems that the task of editing the commentaries of the Byzantine scholar was probably assigned to Max Wallies (1856-1925), the editor of almost all commentaries on the Logica nova in the new series. ${ }^{46}$ According to the reports of the CAG editorial board in the late 1880s, Wallies studied transcriptions of 'Paris manuscripts' that contained Magentenos' commentary on the Top. ${ }^{47}$ Additionally, archival material shows that he collated the text of Magentenos' commentaries on Porphyrios' Isagoge and on the Cat., ${ }^{48}$ as well as on the Anal. Pr. in the codex Coisl. $157 .^{49}$ Wallies' progress was so significant, that the CAG editorial board deemed, already in 1886, that an edition of Magentenos' corpus was viable..$^{50}$ In his overview of the CAG, however, Hermann Usener (1834-1905) relates that the plan was 'tacitly' abandoned after $1889 .{ }^{11}$ In reality, Karl Kalbfleisch $^{52}$ (1868-1946), an associate and editor of the CAG, was still reporting five

42 Monatsberichte 1878, 406.

43 CAGB Database (link to the lemma on p. XXIII). On Magentenos see Torstrik's (a) working journal in Register n. 18, 6 (note on the printed editions of Magentenos' commentaries), 11 (reference to respective passages in Brandis 1836), 36 (citation of Magentenos' works in Par. gr. 1917), 45 (citation of Magentenos' commentaries in Vat. gr. 1018), 66 (a reference to Magentenos' commentary on Int.), 67 (note on the printed edition of the commentary on Anal. Pr.), 138 (citation of Magentenos' commentaries in Vat. gr. 1018); (b) notes on the manuscript tradition of Magentenos' commentaries in Register n. 20.11, ff. 3r, 10r, 11r.

44 Monatsberichte 1876, 223.

45 Monatsberichte 1877, 178.

46 CAG volumes 2.1-3, 4.6, 5.1, 13.2-3, 23.3-4. The only exception is volume 21.1. This was edited by Michael Hayduck (1838-1809) and includes commentaries by Eustratios of Nicaea and an anonymous scholiast on Anal. Post. II.

47 Sitzungsberichte 1886, 334; 1887, 293. These codices must have been the Parisini 1843, 1874, 1917 and Coisl. 157; see Wallies 1891. For the text in Coisl. 157 see also p. LI.

48 Register n. 56.

49 The collations of this commentary are preserved in the margins of one of the three Aldine editions which are kept today in the holdings of the Library of the Berlin-Brandenburg Academy of Sciences and Humanities. For Magentenos' text in the Aldine edition see p. XXVII.

50 Sitzungsberichte 1886, 334.

51 Usener 1892, 1008.

52 CAGB Database (link to the lemma on p. XXIII). 
years later to Hermann Diels ${ }^{53}$ (1848-1922) on the Parisini that transmitted Magentenos' commentary on the Soph. El.54 Finally, as late as 1902, Diels, the successor of Torstrik, observed that there still remained nine commentaries that had not yet been included in the formal list of CAG works (that is, commentaries other than those already published). ${ }^{55}$ No commentary of Magentenos found its way into print within the framework of the CAG project.

Editorial efforts and further study on Magentenos' work have been undertaken later by individual research projects. Sten Ebbesen contributed a significant breakthrough by publishing excerpts from the commentaries on Cat. ${ }^{56}$ and on Soph. El., ${ }^{57}$ as wells as by studying the sources and reception of Magentenos' commentary on Soph. El. ${ }^{58}$ The prooimion to the Top. and the comments on Top. II were edited by Sofia Kotzabassi, ${ }^{59}$ who also examined the reception of this commentary in the late Byzantine period. ${ }^{60}$ Felippe González Calderón has also recently shown that Magentenos used Alexander's commentary on the Top. ${ }^{61}$ Christian Brockmann and Stefano Valente have investigated the manuscript tradition of the commentary on the Anal. Post. ${ }^{62}$

According to Sten Ebbesen, Magentenos' period of writing activity should be dated between the middle of the twelfth and the third quarter of the thirteenth centuries. ${ }^{63}$ Ebbesen's arguments can be summarised as follows:

53 CAGB Database (link to the lemma on p. XXIII).

54 In a letter addressed to Diels (Paris, 9 July 1894) Kalbfleisch remarks the following: 'Was die Übereinstimmung mit Leo Magent. betrifft, so habe ich bereits ganz in der in Ihrem geschätzten Briefe bezeichneten Weise einige Blätter des Cod. Coisl. 167 s. XIV, der den Leo M. enthält, daraufangesehen und in die Abschrift vom A einige Bemerkungen eingetragen, welche, wie ich hoffe zur Feststellung des Verhältnisses genügen werden'. The siglum A is attibuted to Par. gr. 1972, whereas the text with which Magentenos' commentary is compared, is of course the commentary on the Soph. El. that is attributed to Michael of Ephesos; for the letter of Kalbfleisch see Register n. 5.

55 These commentaries should be: Ps.-Themistios (Sophonias) on Parva naturalia (CAG 5.6), Philoponos on Anal. Pr. (CAG 13.2) and on Anal. Post. (CAG 13.3), an anonymous on Anal. Post. II (CAG 13.3), Philoponos (Michael of Ephesos) on Gener. An. (CAG 14.3), Eustratios of Nicaea on Anal. Post. II and an anonymous on the same book (CAG 21.1), Michael of Ephesos on Parva naturalia (CAG 22.1) and on Part. An., Mot. An., Inc. An. (CAG 22.2); see Sitzungsberichte 1902, 45.

56 Ebbesen 1975-76, 383-384; Ebbesen 1981b, II, 278-279. The text in both cases derives from Vat. gr. 244 , ff. $45 \mathrm{v}$ and $37 \mathrm{v}$ respectively.

57 Ebbesen 1981b, II, 280-306. Text and logical diagrams deriving from an earlier version of the comments on Soph. El. in Vat. Urb. gr. 35, as well as further excerpts from Vat. gr. 244 (ff. 585v, 620v, 624v) were published in Bülow - Ebbesen 1982, 55-113 and 114-115 respectively.

58 Ebbesen 1981b, I, 314-322, 333-340.

59 Kotzabassi 1999, 109-152.

60 Kotzabassi 1999, 15-16.

61 González Calderón 2014, 421-430; cf. Kotzabassi 1999, 47.

62 Brockmann 2019, 219-227; Valente 2021a; Valente 2021b.

63 Ebbesen 1981b, I, 303. 
- $\quad$ the terminus ante quem is determined by Ambr. D 54 sup., a manuscript copied in 1272, making it the oldest dated codex that contains Magentenos' comments. ${ }^{64}$

- the terminus post quem is provided by an anonymous commentary on Soph. El., which has as its main source the final version of Michael of Ephesos' comments. This anonymous source was in turn employed by Magentenos for his own work on the Soph. El. The anonymous commentator 'cannot have worked much earlier than 1150', since he quotes scholia attributed to Michael of Ephesos. Michael of Ephesos' floruit is traditionally thought to be after 1118 since he participated in the Aristotelian project of Anna Komnene. ${ }^{65}$

Both arguments point in right direction, but they are not particularly conclusive and give rise to additional questions.

The first question concerns palaeographical desiderata. Vat. gr. 244 is of principal value concerning the manuscript tradition of Magentenos' works. This is not only because the text of many later codices depends directly or indirectly on the Vaticanus, ${ }^{66}$ but also because this textual witness derives from a rather early stage of the tradition. Christian Brandis was the first to examine the codex and deemed it as quite old ('ziemlich alt'). ${ }^{67}$ Giovanni Mercati was the first to date the manuscript to the thirteenth century, ${ }^{68}$ in which he was followed by Diether Reinsch, ${ }^{69}$ Sten Ebbesen, ${ }^{70}$ Jacques Brunschwig $^{71}$ and Sofia Kotzabassi. ${ }^{72}$ The dating of the codex, nevertheless, is in need of further investigation, since certain palaeographical features may in fact indicate an earlier date (see p. LXI).

The second question deals with uncertainties relating to the dating of Magentenos' floruit made by Sten Ebbesen. The use of the final version of Michael's scholia on the Soph. El. by Magentenos' anonymous source does not exclude the possibility that the anonymous was a contemporary of Michael of Ephesos. On the other hand, it is also not absolutely certain whether the commentary on Soph. El. edited by M. Wallies in CAG 2.3 was actually written by Michael. ${ }^{73}$ Furthermore, recent scholarship has

64 The colophon on f. 203r informs the reader that the copyist's task came to an end on 15 July 1272 (on the treatises of Magentenos in this codex see pp. XLVIII, LXXI sqq.).

65 Ebbesen 1981b, I, 300, 303, 305-307.

66 See Kotzabassi 1999, 57 (comments on Top. II) and Ebbesen 1981b, III, 71 (comments on Soph. El.), as well as the stemma codicum on p. LXXIX below.

67 Brandis 1831, 50.

68 Mercati - Franchi de' Cavalieri 1923, 313.

69 The information is found in an unpublished description of the Vat. gr. 244 in the Aristoteles-Archiv (Freie Universität Berlin).

70 Ebbesen 1981b, 314 claims that the main text and scholia in the codex were copied 'probably around 1275'.

71 Brunschwig 2007, LXI.

72 Kotzabassi 1999, 49.

73 Moore 2005, 560; Golitsis 2018, 615; cf. Ebbesen 1981b, I, 283. 
convincingly suggested that Michael's work should not be dated only in light of his participation in Anna's Aristotelian circle, since he might have written his commentaries earlier than that. ${ }^{74}$

Sofia Kotzabassi offers an argument in favour of dating Magentenos' floruit to the thirteenth century, by explaining the absence of some of his works in the aforementioned commentary lists. The older inventories do not include references to all of Magentenos' commentaries, maybe because at the time of their creation he had not yet finished writing those that are 'missing' ${ }^{75}$ Yet, it should not escape our notice that the registers cite texts of influential and identified authors. Anonymously circulating works and - most importantly - commentaries that were still not canonical, could not be included. Besides, these lists should rather not be considered as up to date; for instance, both the Paraphraseis of Int. and Anal. Pr. by Michael Psellos were widely circulating during the Palaeologan period, ${ }^{76}$ but only the first work is mentioned in the oldest inventory (13th c.). ${ }^{77}$

The sources explicitly or tacitly employed in Magentenos' commentary on Anal. Pr. are not particularly illuminating in establishing a probable time frame for Magentenos' floruit either. Comment 134 on Anal. Pr. II is an interesting case, since it is actually an elaborated version of a passage included in an anonymous collection of scholia on Lucian's Vitarum auctio. The oldest manuscript transmitting this text is Marc. gr. 434 (ff. $123 \mathrm{v}-128 \mathrm{v}$ ) which is dated to the eleventh century. ${ }^{78}$ However, we cannot exclude the possibility that the excerpt was of an earlier date than the Marcianus. On the topic of Aristotelian writers, Magentenos quotes Alexander and Philoponos in his comments on Anal. Pr. I, ${ }^{79}$ he cites a passage from Philoponos' commentary on Anal. Post. $\mathrm{I},{ }^{80}$ while the views of Proklos, Marinos and Alexander on the aim (бколо́) of Anal. Pr. II are also mentioned in the first scholion on this book. It is worth noting, however, that the multitude of sources used in the passage cannot be straightforwardly explained. Magentenos may have indeed excerpted material from a scholion

\footnotetext{
74 Golitsis 2018, 610-611.

75 Kotzabassi 1999, 6 (14).

76 Pérez Martín 2013, 164.

77 Wendland 1901, xviii.

78 Mioni 1985, 202-203; the same scholion is transmitted in Vat. Urb. gr. 118 (13 ${ }^{\text {th }}$ c.). See Rabe 1906, V.

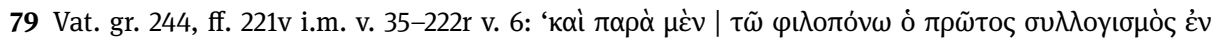

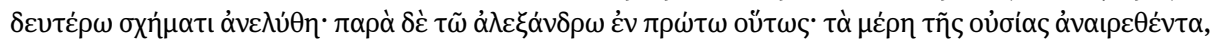

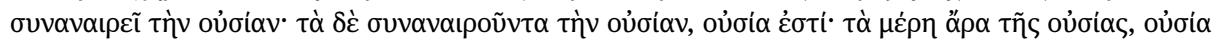

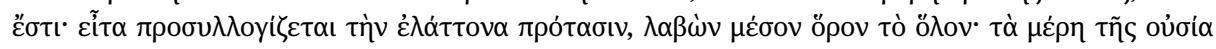

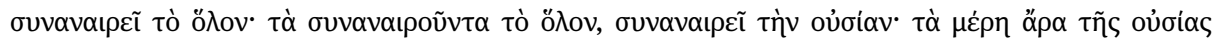

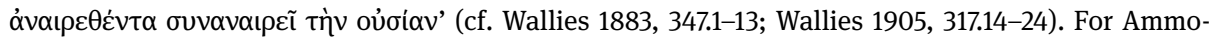
nios as a source of the commentary (or commentaries) of Magentenos on Int. see Bydén 2011, 685. 80 See schol. 152.
} 
attributed to Marinos, ${ }^{81}$ but in the case of Proklos the only information on his commentary on Anal. Pr. derives from Ammonios and a later anonymous commentator on Anal. Pr. I (see p. XLII). ${ }^{82}$ Proklos was held in high esteem by the Byzantines during the eleventh and twelfth centuries, ${ }^{83}$ so the reference to him may be explained as being of this trend. This, in turn, perhaps facilitated the addition of this prominent writer's name to the prooimion. ${ }^{84}$ All three opinions along with an explicit reference to Alexander are found once more in the prooimion of the comments on Anal. Pr. II edited under the name of Philoponos in the CAG series ${ }^{85}$ (see also p. XLII).

There is, however, a passage in Magentenos' commentary on Porphyrios' Isagoge, which hints that the first three quarters of the twelfth century may have in fact been Magentenos' floruit. The text comments on the notion of 'genus' and it is transmitted by all textual witnesses that contain the commentary in its entirety: ${ }^{86}$

\footnotetext{
Porphyrios (Busse 1887, 2.5-7):

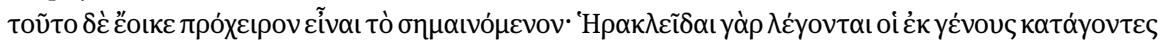

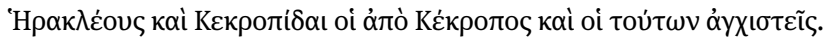

Magentenos (Vat. gr. 244, f. 7rv):

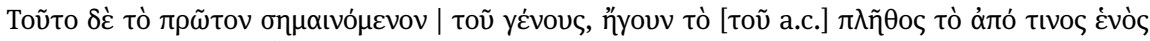

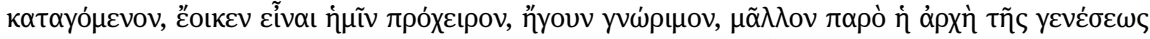

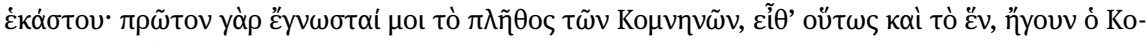

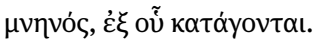

The reference to the Komnenian dynasty (1057-1059, 1081-1185) and the probable allusion to Alexios I are significant pieces of historical information given by the commentator Magentenos himself. Alexios was not the founder of the dynasty, but it was during his reign (1081-1118) that the Komnenoi really came to prominance. ${ }^{87}$ All later Byzantine dynasties (the Angeloi, Lascarides, Palaiologoi, and the Grand Komnenoi) were of course related to the Komnenoi, but nonetheless the appraisal by means of analogies with mythical heroes would have been more plausible during the reign of this enormous family. After all, its members and relatives made up approximately $90 \%$

81 Agiotis 2014, 18.

82 Wallies 1899, 31.24; 39.2 respectively.

83 Trizio 2014, 182-208.

84 Ebbesen 1981a, 10-11.

85 Wallies 1905, 387.6-388.6.

86 Laur. 85.1 (13th-14th c.), f. 11v; Mut. a.V.6.02 (16th c.), f. 6v; Par. Coisl. 157 (15th c.), f. 3v; Par. Coisl. 170 (14th c.), f. 168r; Par. gr. 1845 (13th/14th c.), f. 2r; Par. gr. 1972 (14th c.), f. 9r; Vat. gr. 317 (14th c.), f. 5v. Extracts - save for the abovementioned scholion - are also transmitted in Ambr. M 71 sup. (14th c.), Laur. 71.03 (13th c.), Par. gr. 1928 (14th c.), Par. gr. 2089 (13th c.); to these we might add Laur. Conv. Soppr. 4, ff. 4r-7r (14th c.), whose text we were unable to examine.

87 Magdalino 1993, 27-34. 
of the state elite by the middle of the twelfth century. ${ }^{88}$ To put it differently, such an invocation should not be expected as late as the thirteenth century or during the civil unrest that followed the violent death of the unpopular Andronikos I Komnenos. He had been deposed as emperor in September 1185 by Isaac II Angelos, his political opponent and founder of the next dynasty. ${ }^{89}$

Last, but not least, documents and sigillography may also shed some light on Leon Magentenos' last name; it seems that he was not the only Magentenos in Byzantium. ${ }^{90}$ In spite of insignificant variants in spelling and accentuation, ${ }^{91}$ we also know of one

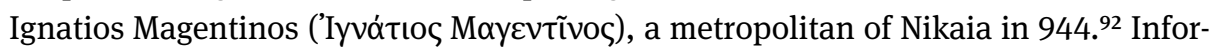

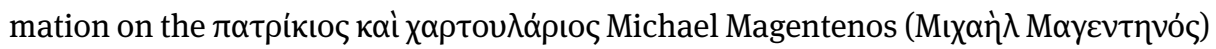

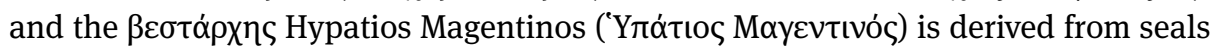
dating to the eleventh century. ${ }^{93}$ Perhaps 'Magentenos' was a family name that bore some indication of relationship to Magentia near Rome ${ }^{94}$ or perhaps Mazenta in Lombardy. ${ }^{95}$ This hypothesis is not improbable, since Byzantium traditionally maintained cultural, political and financial relationships with the Italian peninsula. Even within the context of Byzantine Aristotelianism alone, Ioannes Italos ${ }^{96}$ (ca. 1025 - after 1082), Barlaam the Calabrian ${ }^{97}$ (ca. 1290 - May/June 1348) and Drosos of Aradeo ${ }^{98}$ (14th c.) are all notable examples of this phenomenon.

To conclude, the rich manuscript tradition of Magentenos' commentaries, later sources, as well as the interest taken by recent scholarship make it evident, despite the lack of biographical information, that this prelate was an influential Aristotelian

88 Sorlin 1976, 374; on the 'Komnenian system' of administration and the pivotal role of the imperial family see Magdalino 1993, 180-201.

89 Isaac reigned from 1185 to 1195. For the events before and after the deposition of Andronikos I, see

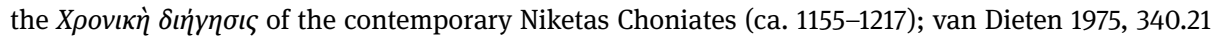
sqq.

90 Wartelle's information that in some manuscripts the scholiast is named Ioannes is not correct (Wartelle 1963, 192 and n. 508, 555, 1060, 1068, 1757).

91 We also register the following three trivial errors: (a) the title of the commentary on Cat. in Par. gr.

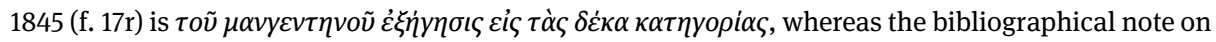
f. Ir informs the reader that the codex contains Categorias, Analytica et Topica, cum Magnentii scholiis; (b) in the title of the printed commentary on Int. attributed to Magentenos (Venice 1503; see p. XXVII), we read Margentinus; (c) Montfaucon 1715, 225 misread $\Lambda$ covtiov in the title of the commentary on

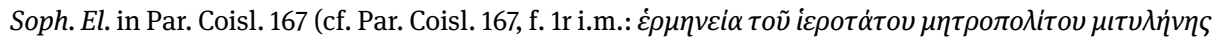

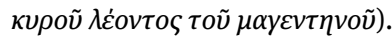

92 Pratsch 2004, 265-268.

93 Jordanov 2006, n. 404 and 404A respectively.

94 Mentioned in the sources since the 13th c.: Contatoris - Corsinus 1706, 428; Toponomastica 1997, 368.

95 Also known since the 13th c.: Toponomastica 1997, 369.

96 Ierodiakonou 2011, 623-625.

97 Trizio 2017.

98 Moraux 1976 et al., 483; PLP, n. 5865, 91834. 
interepreter. He may have been a member of a family providing the Byzantine state with officials as early as the tenth century, while their last name may hint towards a familial origin in the Italian peninsula. Solid information for the dating of Magentenos' treatises is offered by the codex Ambr. D 54 sup. (1272), whereas Vat. gr. 244, which probably contains the entire corpus of Magentenos' works, might have been copied earlier than has been traditionally suggested, that is earlier than the thirteenth century. Other than codicological and palaeographical evidence, Magentenos' sources cannot be traced after the first decades of the twelfth century. Meanwhile, Magentenos himself mentions the Komnenian dynasty in rather positive terms. It is therefore eminently reasonable to consider the period prior to 1185 or even the first half of the twelfth century as being a more suitable floruit for this scholar's writing activities. 